\title{
Comparison of five assays for the heat-labile enterotoxin of Escherichia coli
}

\author{
JAMUNA VADIVELU, D. T. DUNN*, R. G. FEACHEM, B. S. DRASAR†§, N. P. COX, \\ T. J. HARRISON† and B. J. LLOYD‡
}

Departments of Tropical Hygiene and †Medical Microbiology and the "Tropical Epidemiology Unit, London

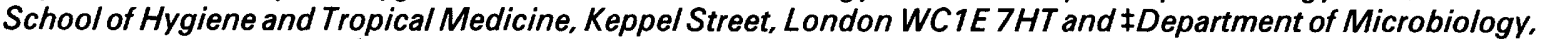
University of Surrey, Guildford, Surrey GU2 $5 X H$

\begin{abstract}
Summary. Enzyme-linked immunosorbent assay (ELISA), DNA-DNA hybridisation, Vero cell assay, the Biken test and a new membrane-filter method were compared in the detection of heat-labile enterotoxin (LT) of Escherichia coli. Six subcultures of each of 50 strains of $E$. coli from the Biken collection were evaluated "blind" in the laboratory. The combined results of the most reproducible tests (ELISA and DNADNA hybridisation) were used to calculate the sensitivity and specificity of the other assays. The Vero-cell assay had a high sensitivity $(98 \%)$ but a lower specificity $(91 \%)$. The Biken and membrane-filter assays had sensitivities of $58-71 \%$ and $77-84 \%$ respectively, depending on the type of antiserum used. Only one false positive result was obtained with the Biken test; specificity of the membrane-filter assay was 94$95 \%$. The membrane-filter assay, with anti-cholera toxin, is specific and reasonably sensitive. It has particular advantages over DNA-DNA hybridisation and the Biken test, and it may prove suitable for screening large numbers of $E$. coli isolates in epidemiological studies in developing countries.
\end{abstract}

\section{Introduction}

Enterotoxigenic strains of Escherichia coli (ETEC) are a major cause of acute diarrhoea in children in developing countries (Ryder et al., 1976; Black et al., 1981), in travellers (Sack et al., 1977; Guerrant et al., 1980) and in sporadic outbreaks amongst children and adults in developed countries (Sack et al., 1975; Rowe et al., 1978; Rosenberg et al., 1978). ETEC produce a non-invasive, secretory diarrhoea by the elaboration of heat-stable enterotoxin (ST) or heat-labile enterotoxin (LT), or both. The LT is a high-mol.-wt immunogenic polypeptide (Clements et al., 1980) and closely resembles the cholera toxin (CT) in structure and activity. It binds to the monosialoganglioside (GM1) residues of the intestinal epithelial cells, causing fluid secretion by stimulating adenyl cyclase activity (Evans et al., 1972; Gill and Richardson, 1980).

Enterotoxin activity was originally detected by fluid accumulation in ligated ileal loops of rabbits (De and Chatterje, 1953; De et al., 1956). A more convenient way of detecting LT is the use of tissue cultures of Vero cells (Speirs et al., 1977) or Y-1 adrenal cells (Sack and Sack, 1975). The immuno-

Received 4 Mar. 1986; revised version accepted 14 Jul. 1986. $\S$ Correspondence should be sent to Dr B. S. Drasar. genic nature of LT allows its detection in immunological assays; enzyme-linked immunosorbent assay (ELISA) (Sack et al., 1980), agglutination tests (Ronnberg and Wadstrom, 1983), and agar diffusion assays, such as the Biken test (Honda et al., 1981) are used. Additionally, the direct detection by DNA-DNA hybridisation of the genes coding for LT production has been described (Moseley $e t$ al., 1980).

These assays detect LT-producing ETEC in different ways and each has advantages and disadvantages in specific applications. We report a laboratory evaluation of the sensitivity, specificity and reproducibility of ELISA, DNA-DNA hybridisation, Vero cell assay, the Biken test and a new membrane-filter method that we have developed.

\section{Materials and methods}

\section{Bacterial strains}

Fifty $E$. coli strains from the Biken collection were donated by Dr B. Rowe (Division of Enteric Pathogens, Central Public Health Laboratory, Colindale). The collection consists of $E$. coli strains isolated at Osaka Airport Quarantine Station from patients with travellers' diarrhoea (Sutton et al., 1985). Some of these strains produce LT. Each strain was subcultured on to five slopes 
of Nutrient Agar (Oxoid) to produce 50 sets of six cultures (parent strain plus five subcultures). Numbers were allocated in random fashion to the 300 cultures and each was tested twice by the five assay methods. If there was disagreement between the two results, a third test was performed and the majority result accepted. The laboratory workers were unaware of the identity of the subcultures with which they worked. E. coli strain 487475 (International Centre for Diarrhoeal Disease Research, Bangladesh) of clinical origin was used as the LT-positive control and E. coli strain WF5 (University of Surrey) of environmental origin was used as the LT-negative control. All strains were subcultured and stored as described by Feltham et al. (1978).

\section{Preparation of culture supernates}

Cell-free culture supernates were prepared according to WHO recommendations (World Health Organization, 1983). Each strain was cultured in $5 \mathrm{ml}$ of Tryptone Soy Broth (Oxoid) containing yeast extract $1 \cdot 2 \%$. Tubes of broth were incubated in a sloped position and with loose caps to provide maximum aeration. After incubation for $48 \mathrm{~h}$ at $37^{\circ} \mathrm{C}$, the cultures were centrifuged at $12000 \mathrm{~g}$ for $15 \mathrm{~min}$ and the supernates were removed for use in the Vero cell assay and ELISA. Commercially-produced cholera toxin (Sigma Chemical Co. Ltd, Poole, Dorset) was used, at concentrations of $1-1000 \mathrm{ng} / \mathrm{ml}$, as positive controls in both these assays.

\section{Antisera}

The following antisera were used: unpurified anticholera toxin (anti-CT, University of Surrey; titre 256000 ); unpurified anti-LT (Virion International Distribution Ltd, Gewerbestrasse 10, CH-6330 Cham, Switzerland; titre 32000 ); affinity purified anti-LT (Meguro Institute, 7-29 Masumi-cho, Ikeda-shi, Osaka 563, Japan; titre 3200); affinity purified anti-LT (World Health Organization, 1211 Geneva 27, Switzerland; titre 600 ). Titres were determined by ELISA titration against CT at a concentration of $1000 \mathrm{ng} / \mathrm{ml}$ of phosphatebuffered saline.

\section{Vero cell assay}

The assay method of Speirs et al. (1977), as modified by Giugliano et al. (1982), was used. The Vero cells were grown in cell medium 199 (Gibco Ltd, Uxbridge, Middlesex) supplemented with fetal calf serum $1 \%$ and a mixture of penicillin $100 \mathrm{IU} / \mathrm{ml}$ and streptomycin $100 \mu \mathrm{g} / \mathrm{ml}$ (Gibco) in 96-well Falcon 3072 tissue-culture plates. The cells were then exposed for $18 \mathrm{~h}$ to $50 \mu \mathrm{l}$ of culture supernate. A positive response was recorded when $50 \%$ or more of the cells showed morphological changes attributable to the cytopathic effect of the toxin.

\section{ELISA}

The ELISA method of Sack et al. (1980), modified by Miller et al. (1986), was used. Culture supernates $(100 \mu \mathrm{l})$ were added to GM1 adsorbed to 96-well Linbro microtitration plates (Flow Laboratories, Rickmansworth, Hertfordshire). Rabbit anti-LT (100 $\mu$ l) (WHO, Switzerland), peroxidase labelled swine anti-rabbit immunoglobulin $(100 \mu$ l) (Dako-Patt, Dako Ltd, High Wycombe, Buckinghamshire) and orthophenylene diamine dihydrochloride $(100 \mu \mathrm{l})$ (Sigma) were then added sequentially and the reaction was stopped after $20 \mathrm{~min}$ by the addition of $2 \cdot 5 \mathrm{M} \mathrm{H}_{2} \mathrm{SO}_{4}(20 \mu \mathrm{l})$. The plates were read spectrophotometrically at $492 \mathrm{~nm}$ by a Flow Multiskan ELISA reader. From the distribution of optical density values obtained in the wells containing supernates prepared from control negative strain WF5, a negative:positive cut-off point of $0 \cdot 26 \mathrm{OD}$ unit was calculated, corresponding to a specificity of $97.5 \%$.

\section{DNA-DNA hybridisation assay}

Hybridisations were performed with a DNA probe derived from the LT recombinant plasmid pAT153H6. A 0.8-kilobase-pair fragment, comprising the LT sequences, was excised from the purified plasmid DNA by digestion with the restriction endonuclease Hind III and separated from the vector by agarose gel electrophoresis. The fragment was then electro-eluted from the gel, purified by DEAE-sephacel chromatography and radiolabelled in vitro with ${ }^{32} \mathrm{P}$ by nick translation (Rigby et al., $1977)$ to a specific activity of $6 \times 10^{7} \mathrm{cpm} / \mu \mathrm{g}$. Colony hybridisations were performed as described by Grunstein and Hogness (1975) and modified by Moseley et al. (1980). Subcultures were spot-inoculated on to nutrient agar, grown at $37^{\circ} \mathrm{C}$ and transferred to nitrocellulose filters (90 mm diameter BA85; Schleicher and Schuell, Anderman, Kingston, Surrey). Bacterial colonies were lysed with $0 \cdot 1 \mathrm{M} \mathrm{HCl}$ and the released DNA was denatured with $\mathrm{NaOH}$. After neutralisation, the single stranded DNA was immobilised on the filters by baking at $80^{\circ} \mathrm{C}$ in vacuo for 1-2 $\mathrm{h}$. Non-specific binding of the probe was blocked by prehybridising the filters with carrier calf thymus DNA. After hybridisation with the radiolabelled LT DNA, the filters were washed and bound probe was detected by autoradiography.

\section{Biken assay}

The Biken test was performed as described by Honda et al. (1981) except that affinity purified anti-LT, unpurified anti-LT and unpurified anti-CT were used. Two subcultures and two control strains were spotinoculated on to a Biken agar plate containing the following constituents (/L): casamino acids (Difco) $20 \mathrm{~g}$; yeast extract (Difco) $10 \mathrm{~g} ; \mathrm{NaCl}$ (BDH Chemicals Ltd, Dagenham, Essex) $2.5 \mathrm{~g} ; \mathrm{K}_{2} \mathrm{HPO}_{4}$ (BDH) $15 \mathrm{~g}$; glucose $(\mathrm{BDH}) 5 \mathrm{~g}$; trace salts solution (BDH; $\mathrm{MgSO}_{4} 5 \%$, $\left.\mathrm{CoCl}_{2} .6 \mathrm{H}_{2} \mathrm{O} 2 \%, \mathrm{FeCl}_{3} 0.5 \%\right) 0.5 \mathrm{ml}$; purified agar (Oxoid) $15 \mathrm{~g}$. The final $p \mathrm{H}$ was adjusted to 7.5. After autoclaving for $15 \mathrm{~min}$ at $121^{\circ} \mathrm{C}$ the medium was cooled to $50^{\circ} \mathrm{C}$ and lincomycin (Sigma) was added to achieve a final concentration of $90 \mu \mathrm{g} / \mathrm{ml}$. After incubation at $37^{\circ} \mathrm{C}$ for $48 \mathrm{~h}$, a well was punched in the agar and a disc 
containing polymyxin B 500 IU (Mast Laboratories Ltd, Merseyside) was placed on each colony. The plates were incubated at $37^{\circ} \mathrm{C}$ for a further $6 \mathrm{~h}$ after which $20 \mu 1$ of antiserum was added to the well. The plates were incubated at $37^{\circ} \mathrm{C}$ and read for lines of precipitation occurring between the colony and well after $24 \mathrm{~h}$ and $48 \mathrm{~h}$.

\section{Membrane-filter assay}

Membrane filtration was performed as described by Vadivelu et al. (1986). Subcultures were spot-inoculated on to $49 \mathrm{~mm}$ cellulose acetate membrane filters $(0.45 \mu \mathrm{m}$ pore size; Gelman Sciences Ltd, Northampton). Four subcultures and two control strains were used per membrane. The membranes were placed on pads soaked in membrane lauryl sulphate broth, containing the following constituents $(/ \mathrm{L})$ : Tryptone Soy Broth (Oxoid) $30 \mathrm{~g}$; yeast extract (Difco) $12 \mathrm{~g}$; sodium lauryl sulphate $(\mathrm{BDH}) 1 \mathrm{~g}$; lactose (BDH) $4 \mathrm{~g}$; cresol red (BDH) $0.2 \mathrm{~g}$. The final $p \mathrm{H}$ was adjusted to 8.5. After overnight incubation at $44^{\circ} \mathrm{C}$, the membranes were transferred on to agar medium containing antiserum (unpurified antiLT, $2.7 \%$, or unpurified anti-CT, $2 \%$, and incubated at $44^{\circ} \mathrm{C}$ for a further $48 \mathrm{~h}$. The formulation of the agar medium was as described for Biken agar (Honda et al., 1981 ) with antiserum added at the appropriate dilution. The optimal dilution of antiserum was determined by testing dilutions of the antiserum in agar against reference ETEC strains known to produce different amounts of enterotoxin as previously determined by ELISA. After incubation at $44^{\circ} \mathrm{C}$ for $48 \mathrm{~h}$, the membranes were removed and the underlying agar was observed for the presence of zones of precipitation.

\section{Results}

\section{Reproducibility}

Table I shows the number of sets of six subcultures, out of a total of 50 sets, in which there was perfect agreement in classification as positive or negative for all subcultures derived from the same parent strain. ELISA was most reproducible (perfect agreement for 45 of 50 sets), followed by DNA-DNA hybridisation assay (42 of 50). Interassay agreement was also very good for these two tests: 276 of the 300 cultures produced the same result with both tests. The other assays were less reproducible, although the Biken test was better than the Vero-cell or membrane-filter assays.

\section{Sensitivity and specificity}

Because it was not known which of the strains prodused LT, we used the combined results of the ELISA and DNA-DNA hybridisation assay to provide the "correct" classification for each strain.
Table I. Reproducibility of methods for assay of LT

\begin{tabular}{lccc}
\hline & \multicolumn{3}{c}{$\begin{array}{c}\text { Number of sets of strains for } \\
\text { which all six cultures gave the } \\
\text { same result }\end{array}$} \\
\cline { 2 - 4 } & Positive & Negative & $\begin{array}{c}\text { Overall } \\
\text { (n=50) }\end{array}$ \\
Assay & 22 & 23 & 45 \\
\hline $\begin{array}{l}\text { ELISA } \\
\text { DNA-DNA hybridisation }\end{array}$ & 21 & 21 & 42 \\
$\begin{array}{l}\text { Vero cell } \\
\text { Membrane filter } \\
\text { (anti-CT unpurified) }\end{array}$ & 21 & 10 & 31 \\
$\begin{array}{l}\text { Membrane filter } \\
\text { (anti-LT unpurified) }\end{array}$ & 12 & 18 & 30 \\
$\begin{array}{l}\text { Biken } \\
\text { (anti-CT unpurified) }\end{array}$ & 8 & 16 & 24 \\
$\begin{array}{l}\text { Biken } \\
\text { (anti-LT unpurified) }\end{array}$ & 8 & 28 & 36 \\
$\begin{array}{l}\text { Biken } \\
\text { (anti-LT affinity-purified) }\end{array}$ & 11 & 26 & 37 \\
\hline
\end{tabular}

There was a total of 12 results for each set of subcultures: six for each of the two assays. A set of six subcultures was defined as "positive" or "negative" if 11 or 12 of these results agreed. This gave rise to 21 positive, 23 negative and six equivocal sets of subcultures. Table II shows the percentage positive results obtained by the Vero-cell, Biken and membrane-filter assays for subcultures classified in this way.

Vero-cell assay showed a very high sensitivity $(98.4 \%)$ but a specificity of $91.3 \%$. Conversely, the sensitivity of the Biken assay was low- $57.9 \%$ for anti-CT, $66.7 \%$ for affinity-purified anti-LT, $71.4 \%$ for unpurified anti-LT-but there was only one false positive result. The sensitivity of the Biken test with anti-CT was significantly lower than with either type of anti-LT $(\mathrm{p}<0.01$ in both cases, McNemar's test). The difference in sensitivity between affinity-purified and unpurified anti-LT was not statistically significant. Table III shows the concordance between results obtained in the Biken test with different antisera. For 262 of the 300 subcultures complete concordance (all tests positive or all negative) was obtained.

The sensitivity and specificity of the membranefilter assay was intermediate between those of the Vero-cell assay and the Biken test. The sensitivities were $84.1 \%$ and $77.0 \%$ for anti-CT and anti-LT, respectively; only seven false positives were obtained with anti-CT (specificity $94.9 \%$ ) and nine false positives with anti-LT (specificity $93.5 \%$ ). The difference between the sensitivity values for the 
Table II. Sensitivity and specificity of the Vero-cell, membrane-filter and Biken assays; subcultures were assigned to "negative", "positive" or "equivocal" categories on the basis of ELISA and DNA-DNA hybridisation results

\begin{tabular}{lllll} 
& \multicolumn{3}{c}{$\begin{array}{c}\text { Percentage of subcultures in each category that gave } \\
\text { positive results in }\end{array}$} \\
\cline { 2 - 5 } the assay indicated \\
\cline { 2 - 5 } Assay & $\begin{array}{c}\text { Negative } \\
(\mathrm{n}=138)\end{array}$ & $\begin{array}{c}\text { Positive } \\
(\mathrm{n}=126)\end{array}$ & $\begin{array}{c}\text { Equivocal } \\
(\mathrm{n}=36)\end{array}$ & $\begin{array}{c}\text { Total } \\
(\mathrm{n}=300)\end{array}$ \\
\hline Vero cell & $8 \cdot 7$ & $98 \cdot 4$ & $58 \cdot 3$ & $52 \cdot 3$ \\
Membrane filter (anti-CT unpurified) & $5 \cdot 1$ & $84 \cdot 1$ & $61 \cdot 1$ & $45 \cdot 0$ \\
Membrane filter (anti-LT unpurified) & $6 \cdot 5$ & $77 \cdot 0$ & $52 \cdot 8$ & $41 \cdot 7$ \\
Biken (anti-CT unpurified) & 0 & $57 \cdot 9$ & $41 \cdot 7$ & $29 \cdot 3$ \\
Biken (anti-LT unpurified) & $0 \cdot 7$ & $71 \cdot 4$ & $33 \cdot 3$ & $34 \cdot 3$ \\
Biken (anti-LT affinity-purified) & 0 & $66 \cdot 7$ & $36 \cdot 1$ & $32 \cdot 3$ \\
\hline
\end{tabular}

two antisera borders on statistical significance $(\mathrm{p}=0 \cdot 07)$. Results obtained with anti-CT and antiLT agreed for 268 of the 300 subcultures (table IV).

\section{Discussion}

To define the sensitivity and specificity of an assay, the correct result for each sample must be known. In the present study, the results of the ELISA and DNA-DNA hybridisation assays were combined in defining the correct result; this is justified by the accuracy and reliability of these assays and by the high levels of reproducibility and agreement achieved in this study. By defining strains for which ELISA and DNA-DNA hybridisation assays disagreed as "equivocal", the possibility of misclassifying strains that code for but do not produce LT (positive by DNA-DNA hybridisation assay, negative by ELISA) and strains that express LT-like molecules that cross-react with antisera to LT (positive by ELISA, negative by DNA-DNA hybridisation assay) was excluded.

Table III. Comparison of different antisera in the Biken test

Result obtained with

\begin{tabular}{cccc}
\hline $\begin{array}{c}\text { anti-CT } \\
\text { unpurified }\end{array}$ & $\begin{array}{c}\text { anti-LT } \\
\text { unpurified }\end{array}$ & $\begin{array}{c}\text { anti-LT } \\
\text { affinity-purified }\end{array}$ & $\begin{array}{c}\text { Number of sub- } \\
\text { cultures }\end{array}$ \\
\hline- & - & - & 185 \\
- & - & + & 5 \\
- & + & - & 13 \\
- & + & + & 9 \\
+ & - & - & 1 \\
+ & - & + & 6 \\
+ & + & - & 4 \\
+ & + & + & 77 \\
\hline
\end{tabular}

The terms sensitivity and specificity are used guardedly. First, these are not fixed values; the sensitivity of an assay is related to the degree of positivity of the sample under test, and the specificity depends upon the presence, or otherwise, of possible cross-reacting molecules. It is valid to compare the sensitivities, or specificities, of two tests only when they have been computed from the same set of samples as we have done. Second, it is possible, but unlikely, that ELISA and the DNADNA hybridisation assay might both misclassify a subculture. Third, the samples defined as equivocal in table II may represent bacteria that produce LT in small amounts or that produce biochemicallyrelated products (Yolken et al., 1977). If the correct result is "positive" the sensitivity of a test may be lower than estimated here; specificity may be reduced if the correct result is "negative". In table II, the sensitivity of each assay is the figure shown in the "positive" column; the specificity is obtained by subtracting the figure in the "negative" column from 100 .

The Vero-cell assay was sensitive, but not very specific. The low specificity can be explained by the cytopathic effects of bacterial products other

Table IV. Comparison of different antisera in the membrane-filter assay

\begin{tabular}{ccc}
\hline \multicolumn{2}{c}{ Results obtained with } & \\
\cline { 1 - 2 } $\begin{array}{c}\text { anti-CT } \\
\text { unpurified }\end{array}$ & $\begin{array}{c}\text { anti-LT } \\
\text { unpurified }\end{array}$ & $\begin{array}{c}\text { Number of sub- } \\
\text { cultures }\end{array}$ \\
\hline- & - & 154 \\
- & + & 11 \\
+ & - & 21 \\
+ & + & 114 \\
\hline
\end{tabular}


than LT (Giugliano et al., 1982), so that it is difficult to obtain reproducibly negative results. The specificity of the assay can be increased by adding a predetermined dilution of antitoxin to a duplicate series of tests.

The membrane-filter and Biken assays were statistically less sensitive than the other assays. In gel assays precipitation complexes dissolve in the presence of excess antigen or antibody and it is thus difficult to define an optimal concentration of antitoxin that will detect the different levels of enterotoxin produced by different strains of ETEC. In the Biken test, precipitation lines were occasionally hidden under the bacterial colony. Moreover, because these assays rely on release of sufficient enterotoxin, a strain that grows poorly, or one that produces a small amount of enterotoxin may be incorrectly classified as negative. Sensitivity will also be reduced if the agar medium impedes the diffusion of toxin and antitoxin.

The membrane-filter assay proved substantially more sensitive than the Biken test, regardless of antiserum used (table II). The reverse might have been expected because the Biken test can detect both intracellular and extracellular LT by the use of polymyxin B, whereas the membrane-filter assay detects mainly extracellular LT. The specificity of the Biken assay was good; only one "negative" subculture was misclassified. The membrane-filter assay misclassified $5-6 \%$ of "negative" subcultures (table II).

The reproducibility of the Biken test was also better than that of the membrane-filter assay (table I). More sets of subcultures showed perfect negative agreement, whereas the number of sets showing perfect positive agreement was similar for the two assays. Further analysis of the data identifies one class of "positive" sets that both assays could identify correctly and consistently, and a second class that they could not. In the second class, the membrane filter assay identified more positive strains than the Biken test, although it seldom achieved consistency over the six related subcultures.

The use of different antisera in the gel diffusion assays gave rise to discordant results with a few subcultures: 32 of 300 in the case of the membrane-

\section{REFERENCES}

Black R E, Merson M H, Huq I, Alim A R M A, Yunus M 1981 Incidence and severity of rotavirus and Escherichia coli diarrhoea in rural Bangladesh. Implications for vaccine development. Lancet, $1: 141-143$.

Clements J D, Yancey R J, Finkelstein R A 1980 Properties of filter assay (table IV), and 38 of 300 in the case of the Biken test (table III). Most discordances occurred with "positive" subcultures and resulted in different sensitivities for tests in which the different antisera were used (table II). Use of antiCT rather than anti-LT improved the sensitivity of the membrane-filter assay, but reduced the sensitivity of the Biken test. This may be due to the different concentrations at which the antisera were used. Anti-LT was used in the Biken test at the concentration recommended by the commercial suppliers, whereas we determined the optimal concentrations of antisera for all the other assays.

The average number of $E$. coli isolates that can be screened per $\mathrm{ml}$ of antiserum varies between assays: 720 isolates with controls can be screened by ELISA per $\mathrm{ml}$ of antiserum used at a dilution of 1 in 100 (more with high titre antisera); about 200 isolates can be screened by the Biken test, depending on the number of controls used; between 370 and 500 isolates, including controls, can be tested by the membrane-filter assay, depending on whether the antiserum in the agar is used at a concentration of $2.7 \%$ or $2.0 \%$.

In the present study, in which each test was repeated up to three times and the majority result taken as the correct one, the membrane-filter assay with anti-CT had a specificity of $95 \%$ and a sensitivity of $84 \%$. A clinical laboratory would usually perform the assay only once and in these circumstances the specificity would be reduced to $93 \%$ and the sensitivity to $79 \%$ (calculations not shown). However, this sensitivity is still substantially better than those achieved by the Biken test, even with three repetitions (table II).

The membrane-filter assay with anti-CT appears to be worth further development and field testing. It may be especially suitable for laboratories with limited facilities that undertake investigations of ETEC transmission and environmental risk factors.

This study was supported by the Medical Research Council, grant G8324074/T. We thank the World Health Organization, Geneva, for their kind gift of purified anti-LT; Virion Institut, Zurich, for the unpurified anti-LT; Dr B. Rowe, Central Public Health Laboratory, Colindale, for providing us with bacterial strains; and Drs Y. Takeda and N. F. Pierce for their advice and assistance.

homogeneous heat-labile enterotoxin from Escherichia coli. Infection and Immunity, 29:91-97.

De S N, Chatterje D N 1953 An experimental study of the mechanism of action of Vibrio cholerae on the intestinal mucous membrane. Journal of Pathology and Bacteriology, $66: 559-562$.

De S N, Bhattacharya K, Sarkar J K 1956 A study of the 
pathogenicity of strains of Bacterium coli from acute and chronic enteritis. Journal of Pathology and Bacteriology, 71:201-209.

Evans D J, Chen L C, Curlin G T, Evans D G 1972 Stimulation of adenyl cyclase by Escherichia coli enterotoxin. Nature, New Biology 236: 137-138.

Feltham R K A, Power A K, Pell P A, Sneath P H A 1978 A simple method for storage of bacteria at $-76^{\circ} \mathrm{C}$. Journal of Applied Bacteriology, 44:313-316.

Gill D M, Richardson S H 1980 Adenosine diphosphateribosylation of adenylate cyclase catalyzed by heat-labile enterotoxin of Escherichia coli: comparison with cholera toxin. Journal of Infectious Diseases, 141:64-70.

Giugliano L G, Mann G F, Drasar B S 1982 Response of mammalian cell lines to the toxins of Escherichia coli. Journal of Medical Microbiology, 15: 531-539.

Grunstein M, Hogness DS 1975 Colony hybridization : a method for the isolation of cloned DNAs that contain a specific gene. Proceedings of the National Academy of Sciences of the USA, 72:3961-3965.

Guerrant R L, Rouse J D, Hughes J M, Rowe B 1980 Turista among members of the Yale Glee Club in Latin America. American Journal of Tropical Medicine and Hygiene, 29:895900.

Honda T, Taga S, Takeda Y, Miwatani T 1981 Modified Elek test for detection of heat-labile enterotoxin of enterotoxigenic Escherichia coli. Journal of Clinical Microbiology, 13:15.

Miller C J, Drasar B S, Feachem R G, Hayes R J 1986 The impact of physico-chemical stress on the toxigenicity of Vibrio cholerae. Journal of Hygiene, 96:49-57.

Moseley S L, Huq I, Alim A R M A, So M, Samadpour-Motalebi M, Falkow S 1980 Detection of enterotoxigenic Escherichia coli by DNA colony hybridization. Journal of Infectious Diseases, 142:892-895.

Rigby P J W, Dieckmann M, Rhodes C, Berg P 1977 Labeling deoxyribonucleic acid to high specific activity in vitro by nick translation with DNA polymerase 1. Journal of Molecular Biology, 113:237-251.

Ronnberg B, Wadstrom T 1983 Rapid detection by a coagglutination test of heat-labile enterotoxin in cell-lysates from blood agar-grown Escherichia coli. Journal of Clinical Microbiology, 17: 1021-1025.
Rosenberg M L et al. 1977 Epidemic diarrhea at Crater Lake from enterotoxigenic Escherichia coli: a large waterborne outbreak. Annals of Internal Medicine, 86:714-718.

Rowe B, Gross R J, Scotland S M, Wright A E, Shillom G N, Hunter N J 1978 Outbreak of infantile enteritis caused by enterotoxigenic Escherichia coli O6.H16. Journal of Clinical Pathology, 31 : 217-219.

Ryder R W et al. 1976 Infantile diarrhea produced by heatstable enterotoxigenic Escherichia coli. New England Journal of Medicine, 295:849-853.

Sack D A, Sack R B 1975 Test for enterotoxigenic Escherichia coli using $\mathrm{Y} 1$ adrenal cells in miniculture. Infection and Immunity, 11 :334-336.

Sack D A et al. 1977 Enterotoxigenic Escherichia coli diarrhoea of travelers: a prospective study of American Peace Corps volunteers. Johns Hopkins Medical Journal, 141 :63-70.

Sack D A, Huda, S, Neogi P K B, Daniel R R, Spira W M 1980 Microtiter ganglioside Enzyme Linked Immunosorbent Assay for Vibrio and Escherichia coli heat-labile enterotoxins and antitoxin. Journal of Clinical Microbiology, 11:35-40.

Sack R B, Hirschhorn N, Brownlee I, Cash R A, Woodward W E, Sack D A 1975 Enterotoxigenic Escherichia coliassociated diarrheal disease in Apache children. New England Journal of Medicine, 292:1041-1045.

Speirs J I, Stavric S, Konowalchuk J 1977 Assay of Escherichia coli heat-labile enterotoxin with Vero cells. Infection and Immunity, 16:617-622.

Sutton R G A et al. 1985 Evaluation of the Biken test for detection of LT-producing Escherichia coli. In: Takeda Y, Miwatani T (eds) Bacterial diarrheal diseases. Martinus Nijhoff, Tokyo, pp 209-218.

Vadivelu J, Lloyd B J, Drasar B S, Feachem R G, Cox N P, Harrison T J 1986 Membrane filter assay for detection of enterotoxigenic Escherichia coli in epidemiological studies. Lancet, 1 : 1007-1009.

World Health Organization 1983 Manual for laboratory investigations of acute enteric infections. CDD/83.3. Geneva: World Health Organization.

Yolken, R H, Greenberg H B, Merson M H, Sack R B, Kapikian A Z 1977 Enzyme-linked immunosorbent assay for detection of Escherichia coli heat-labile enterotoxin. Journal of Clinical Microbiology, 6:439-444. 